\title{
Introduction
}

\section{THE BOOK}

It would be difficult to overstate the importance of The Story of the Stone, also known as The Dream of the Red Chamber (Honglou meng), in the Chinese cultural canon. The book is Paradise Lost, War and Peace, In Search of Lost Time, and Pride and Prejudice all rolled into one.

The novel has all the elements of a well-crafted soap opera. It is set in an opulent residential compound where two adjacent mansions are occupied, respectively, by the two branches of the Jia clan, the Rong and the Ning. Thanks to the military feats of their ancestors, the Jias enjoy close ties to the imperial house. The story focuses on the Rong branch, where the matriarch's favorite grandson and the hope of his generation is supposed to be studying for the civil service examinations, but instead idles away his time in the company of his girl cousins and maidservants. Toward the end of the novel, the clan faces ruin from the cumulative effects of the recklessness and incompetence of its senior members. Thus, the book offers us a peek into the lavish lifestyles of the rich, exposes their machinations, and shows us how everything can end in tears.

Through adaptation into movies, television dramas, and theme parks over the years, even Chinese who have never read a single page of The Story of the Stone have become familiar with its basic plot. Some of its most famous scenes are so deeply imprinted on the popular imagination that one needs only to say "Grannie Liu in Prospect Garden" to elicit indulging smiles over someone's faux pas-Grannie Liu being a peasant woman in the novel who was stupefied by the magnificence of the Jia compound. The story has come to serve as a common frame of reference for people of all different backgrounds.

Yet this popular novel is also hugely ambitious. The Jia household presents a microcosm of the world as the author knew it. As the story unfolds, 
a panoramic picture emerges of eighteenth-century Chinese society-a culture in the final moments of its glory before the intrusion of Western values. Embedded in the picture is an unsentimental critique of that society. Moreover, by casting the narrative within a mythic framework in which our hero, in his rebellion against Confucian strictures, is mysteriously guided by a Buddhist monk and a Taoist, the author presents his own perspective on the relationship of Confucianism, Buddhism, and Taoism.

The characters of this novel interact as though each is propelled solely by his or her own inner needs, which gives the readers the illusion of watching real people in action. This narrative technique was not widely employed by Western fiction writers until the nineteenth century. Also unusual at such an early stage in the evolution of the novel, female characters are assigned central roles, and even lowly maidservants have distinctive voices.

\section{THE AUTHOR AND THE MANUSCRIPTS}

Little is known today about the author, Cao Xueqin (1715?-1764?). There is, however, abundant historical documentation relating to his family that strongly suggests the novel may be semiautobiographical. The fortunes of the Jia family in the novel echo those of Cao's own.

Cao Xueqin's great-great-grandfather was a military man from the Han, the dominant ethnic group in China. He earned the trust of the Manchu people, who, in 1644, conquered China and established the Qing, the last imperial dynasty. His son, Cao Xi, became an imperial bodyguard, and his daughter-inlaw was wet nurse to the boy who, in 1661, ascended the throne as the Kangxi Emperor. Cao Yin, Cao Xi's son and Cao Xueqin's grandfather, was Kangxi's childhood playmate. As Cao Yin was known for his poetic sensibilities, Kangxi later commanded him to compile a complete collection of poems from the Tang dynasty that is still widely used today. Kangxi also appointed Cao Xi to the post of imperial textiles commissioner-responsible for procuring textile products for the imperial household-whereupon the family moved from Beijing to the commercial center of Nanjing in the south. The Caos managed to hold onto this immensely prestigious and lucrative post for three generations. The family was wealthy enough to maintain a private Kun opera troupe and played host to Kangxi four times on the latter's inspection tours of the south. Two of Cao Xueqin's aunts were made princesses. The Caos' reputation 
as the emperor's close informants must have added immeasurably to their power and wealth. However, after Kangxi's long reign ended, a power struggle ensued, and after his son Yinzhen ascended to the throne as the Yongzheng Emperor, he threw Cao Xueqin's father (or perhaps his uncle) into prison and confiscated the family's fortune.

Cao Xueqin was about thirteen when this calamity struck. He spent the rest of his life in Beijing, barely making a living by selling his paintings. It is not known how much of the novel is based on actual events, although notes left by some early readers on the margin of an extant manuscript copy of the novel contain such tantalizingly suggestive remarks as "Well said!," "She was just like that," and "No, that's not how it happened!"

The novel was not printed until several decades after the author's death. Twelve manuscript copies of the first eighty chapters have survived, suggesting that these had been privately circulated among Cao's relatives and friends. By contrast, no complete manuscript copy of the last forty chapters has been found. According to the preface of the first printed edition (1791), the editors had to "patch together" the final third of the novel from more than twenty chapters held in private collections and another ten or so fragmentary chapters purchased from a dealer.

This raises the issue of the authenticity of the last forty chapters. In our opinion, the story is far too complicated for any significant portion of it to have been produced independently by someone else. Nearly all the narrative threads left dangling in the first eighty chapters are resolved satisfactorily in the last forty chapters. There are a few minor inconsistencies, but this is inevitable in a novel that runs to thousands of pages in print when the author has labored over it for a decade without the benefit of modern word processing. Inconsistencies notwithstanding, the quality of the latter narrative is very high, much of it brilliant. Furthermore, the deep compassion with which the author embraces humanity, as well as his unique ability to endow each character with a distinctive voice, remains consistent throughout, something that would be nearly impossible for anyone else to simulate.

If we accept that the last forty chapters are also from Cao Xueqin's hand, why did the author keep them so close to the vest? He may still have been working on them when he died, or he could have feared that the Qianlong Emperor-Kangxi's grandson, notorious for his literary inquisitions-might 
take umbrage at references to his father's political purges (alluded to in the final third of the novel).

There are minor variations among the extant editions of the novel. A lineby-line comparison leads us to the conclusion that those based on the 1792 Cheng Yi edition (Cheng's Second Edition) contain the fewest errors. This guide is keyed to the English translation by David Hawkes (1923-20o9), who resigned his position as chair of Chinese at Oxford University in order to translate the first eighty chapters of the novel, and John Minford, who completed the last forty chapters.

\section{THE PRIMARY CHARACTERS}

The Story of the Stone features a cast of hundreds. Even Chinese familiar with some of the personalities through cultural osmosis have problems keeping them straight. Diagrams of the family tree and one-line descriptions of the characters are found at the back of each of the five volumes of the Hawkes and Minford edition. Here, as a preview, is a brief description of the leading characters.

Our hero, Jia Bao-yu, is a sensitive boy who rebels against the social role assigned to him. He is expected to let women cater to him so that he can focus on studying for the civil service examinations and eventually take his place at court or in the bureaucracy, where he can advance the interests of his clan. Unfortunately, he finds the male world to be filled with bluster and vainglory and prefers the company of his female cousins and his maidservants, whom he treats as his equals. Bao-yu's father feels his son is perverse and treats him with contempt, but Grandmother Jia-who has the last word in the domestic sphere-sees nothing wrong with her favorite grandchild.

Bao-yu's soul mate is his paternal first cousin, Lin Dai-yu, whose deceased mother was his father's sister. Grandmother Jia sends for Dai-yu so that she can grow up by her side, rather than be raised by her widowed father. Proud and sensitive, physically and emotionally fragile, Dai-yu is ever conscious of her status as a poorer relation who does not quite belong to the Jia household. She and Bao-yu fall in love. Her predicament is that, although there is no rule against first cousins marrying (as long as they have different family names), marriages are arranged by parents, and Dai-yu, whose father soon dies, has no one to speak for her. 
Lin Dai-yu's rival in love, Xue Bao-chai, is another first cousin of Bao-yu, her mother being his mother's sister. Bao-chai-together with her widowed mother, Aunt Xue, and her brute of a brother, Xue Pan-flees their hometown after Xue Pan commits manslaughter. At the invitation of Bao-yu's mother, they move into a corner of the Jia compound, bringing their wealth with them. Unlike the high-strung Dai-yu, Bao-chai is sensible and tactful, and she is careful not to offend anyone in the household, especially since an inscription given to her by a monk hints that she is destined to marry someone like Bao-yu.

Bao-yu's father, Jia Zheng, is Grandmother Jia's second son and a well-meaning but mediocre bureaucrat. His chief wife, Lady Wang, bore him a daughter and two sons. Their daughter, Yuan-chun, is a titled concubine highly favored by the reigning emperor. By the time the novel begins, their older son has died, leaving a young widow, Li Wan, to raise their child, Jia Lan, by herself. Bao-yu is Lady Wang's younger son. Jia Zheng also has two concubines, one of whom, "Aunt" Zhao, is constantly simmering with resentment over people's lack of respect for herself and her oafish son, Jia Huan. Aunt Zhao also has a daughter, the capable Tan-chun, who tries to distance herself from her disagreeable birth mother.

Grandmother Jia's elder son, Jia She, is the ranking male of the Rong branch, the junior branch of the Jia clan. However, he is eclipsed by his younger brother because he does not have a daughter favored by the emperor and also because he has built a reputation for being self-indulgent and lecherous. His first wife, now dead, bore him a son, Jia Lian, who married Lady Wang's niece, Wang Xi-feng, a vivacious and shrewd young lady whom Grandmother Jia has put in charge of overseeing the operations of the Rong household. The young couple has only a daughter, Qiao-jie, who remains a little girl through most of the novel. Jia She also has a daughter, the timid Ying-chun, by a concubine. At the time the novel opens, Jia She's chief wife is Lady Xing, a childless, selfish woman who thoughtlessly takes up the causes of her goodfor-nothing husband.

The head of the Ning branch, the senior branch of the Jia clan, is another lecher, Jia Zhen ("Cousin Zhen" in the English translation because, although much older, he belongs to the same generation as our hero, Bao-yu). He has inherited the aristocraticl title because his father, Jia Jing, has withdrawn to a Taoist monastery. Even though Cousin Zhen has a wife, You-shi, and two 
concubines, he remains on the prowl. The novel hints heavily that he has had an affair with Qin-shi, the wife of his son, Jia Rong. In disgust at these goings on, Jia Zhen's much younger sister, Xi-chun, turns to Buddhism and eventually becomes a nun.

Jia Yu-cun, a corrupt scholar-official, is a distant relative of the Jias.

Hawkes and Minford have helpfully translated the servants' names into English to distinguish them from the upper-class characters in the novel. Especially notable are Grandmother Jia's chief maid, Faithful; Wang Xi-feng's chief maid, Patience; Jia Bao-yu's chief maid, Aroma, and his personal maid, Skybright; and Lin Dai-yu's chief maid, Nightingale. (However, the names of stewards and stewardesses-who, at the Jia household, are authority figuresare transliterated, like those of their employers.) The stage names of actors and actresses are translated into French. In the case of the religious clerics, their names are translated into Latin, or they are given titles corresponding to Roman Catholic Church usage.

To further help readers unpack the web of relationships among the major figures in the novel, we offer a "Key to Recurring Characters" following this introduction.

\section{THE BASIC PLOT}

It may be said that The Story of the Stone does not get moving until the second or even the third chapter. Chapter 1 establishes the mythological backstory: in a previous life, Jia Bao-yu was a stone, and Lin Dai-yu was a flower that owed the stone a debt of tears for keeping her watered; as a result, the two were sent down to the human world to work out their karmic bond. Only in chapter 2 do we enter the realm of the here and now, as we are given an overall view of the Jia household through the cold, appraising eyes of an antique dealer. The antique dealer tells Jia Yu-cun-who will soon chaperone his student Lin Dai-yu to the capital, where she will live with Grandmother Jia-that, with no son capable of looking after its interests, this once powerful family is in inexorable decline. Chapter 3 begins with Lin Dai-yu arriving at the Rong house to find her grandmother surrounded by a bevy of pretty young girls-her cousins and their large retinues of maids-all dressed in gorgeous finery. She is shocked by the liberties that the extroverted Wang Xi-feng is allowed to take with Grandmother Jia, despite still being a young woman scarcely out of her teens. 
As it turns out, Wang Xi-feng and her equally young husband are the only ones in the household fully aware of its precarious finances. The senior members refuse to face up to the situation, and the younger ones do not consider it their business. Regardless, however, the Jias keep up a flourishing appearance.

Luck seems to improve for the Jia clan when Bao-yu's oldest sister, Yuanchun, is elevated from lady-in-waiting to the position of Imperial Concubine. A large garden dotted with fancy cottages is carved out of the family compound to receive her on her visit. Afterward, the adolescent Bao-yu, his half-sister Tan-chun, and their girl cousins, along with their many servants, are allowed to move into the garden, each occupying a cottage. The bulk of the remaining narrative takes place in this garden. After Yuan-chun dies, leading members of the family are indicted for various crimes, and a harrowing raid is made on the compound. However, at the end, the novel holds out hope that, with the birth of a new generation, the family may prosper again one day.

The tragic love story of Jia Bao-yu and Lin Dai-yu is woven into this tale of family decline. Even though Bao-yu's grandmother and mother know that he is in love with Dai-yu, they eventually decide that he should marry his other cousin, the genial and capable Xue Bao-chai. From a pragmatic point of view, Bao-chai is much the better choice because Bao-yu's bride will one day be responsible for running the large and complicated household-a role that Dai-yu is demonstrably unfit to perform. Bao-yu is duped into thinking he is marrying Dai-yu, and it is not until he lifts up the bride's veil after the ceremony that he learns the truth. Meanwhile, the frail Dai-yu dies of heartbreak.

To Bao-yu, this betrayal is the final blow in a long series of misfortunes-illness, suicides, and mistreatment by abusive husbands-that, one by one, have befallen all the beloved girls in his life. He comes to the realization that everything is ephemeral and one's destiny lies beyond one's control. After dutifully impregnating his wife to give the family an heir and bringing honor to the family by excelling on the examinations, he leaves the world behind to become a monk.

\section{THE PHILOSOPHICAL FRAMEWORK}

How does one come to terms with a paradise lost? One way is to admit that change is in the nature of life itself. That's the Taoist (Daoist) view. Another way is to develop an attitude of emotional detachment, which is a Buddhist 
ideal. Throughout the novel, the author pits Taoism and Buddhism against Confucianism, the upbeat and utilitarian ideology of the establishment.

It is possible to read The Story of a Stone as a Taoist story. Taoism holds that human nature is like an uncarved piece of jade that becomes blemished and soiled as one goes through life. At the beginning of the book, readers are told that Bao-yu is an incarnation of a stone left over from the pile that the goddess Nüwa used to repair a hole in the sky. This is why he was born with a piece of jade in his mouth and why his family named him Bao-yu, which means "precious jade." As the story unfolds, it becomes clear that the jade has magical properties. All the characters in the novel with yu in their names are endowed with the ability to rise above mundane concerns, manifested in their physical appearance as ethereal beauties. At the end of the novel, Bao-yu leaves the mundane world behind and ultimately returns to being a stone.

It is also possible to read The Story of a Stone as a Buddhist tale of how one man attains enlightenment. Like Siddhartha Gautama, the historical Buddha, Bao-yu is born into luxury and, as a child, shielded from life's miseries. As he is exposed to human suffering, he gradually becomes convinced that worldly pleasures are illusory and that true happiness-that is, liberation from suffering-can be attained only by renouncing all human ties. The coup de grâce comes when he is tricked by his own family into marrying the wrong girl while his soul mate dies of a broken heart. Bao-yu may be seen as a Buddha-like figure, just as Prince Myshkin is a Christ-like figure in Fyodor Dostoyevsky's The Idiot, although unlike Buddha or Christ, neither is able to transcend his earthly nature to help humanity.

But what of Confucianism, with its respect for social hierarchy and personal loyalty to kith and kin? In the novel, Confucianism serves, all too often, as a cover for the powerful and the well connected to rig the system in their own favor. However, it is also clear that the author recognizes the important role of Confucian ethics in the smooth functioning of Chinese society. Confucian teachings set the ground rules for decency, thereby drawing the line that delimits the most egregious forms of bad behavior. In fact, the fall of the Jia clan can ultimately be attributed to its neglect of two fundamental Confucian virtues: frugality and moderation.

Incidentally, Taoism the philosophy is distinct from Taoism the eclectic religion, which can be best described as an amalgam of all kinds of ancient Chinese folk beliefs imbedded with strands of Taoist philosophy. The author 
of the novel exploits the blurry line between the two, by clothing the philosopher in religious garb, as it were. He approves of the philosophy but makes fun of the religion. The Hawkes and Minford translation generally uses the term "Taoist" to refer to a Taoist philosopher and "priest" to designate a clergyman. Readers may wonder why both Buddhist and Taoist clergies are invited to participate in many large ceremonies in the novel. The fact is that, by the eighteenth century, Buddhism and Taoism had become inextricably linked in the syncretic popular belief of the Chinese.

Whether they are Buddhist, Taoist, or Confucian, most Chinese believe in some kind of fate-that is, they believe that much of life lies beyond our control. In Buddhism, fate describes the process by which one's karma (good and bad deeds accumulated in one's current and previous lives) works itself out. The author uses the concept of fate to lend a sense of inevitability to the progression of events, although he makes clear that fate works itself out through a convergence of people's temperaments and their circumstances. Whenever it suits his artistic purposes, the author also deploys fate as a device to create a mood of foreboding, as when the characters have presentiments of things to come. These are sometimes revealed in the form of Freudian slips, as the author shows, with startlingly modern insight, how presentiments can often be explained in terms of one's ability to sense intuitively what one is not yet able to acknowledge with one's rational mind. Time and again, Cao Xueqin, who predated Sigmund Freud by a century and a half, astonishes us with his psychological acumen.

At the end of the novel, the news that Bao-yu is missing reaches his father while he is away from home. Sitting in the cabin of a boat at anchor, he is in the act of writing a response when he lifts his eyes to see a monk bowing deeply to him out on the deck. By the time he recognizes the man to be his own son, Bao-yu has been hustled ashore by a Buddhist monk and a Taoist. Jia Zheng rushes after them but fails to catch up. It then dawns on him that Bao-yu is a being from a higher realm who does not belong to this world. Thus, father and son-and, symbolically, Confucianism, Buddhism, and Taoismcome to terms with each other and affirm each other's legitimacy.

\section{APPROACHES TO READING THE NOVEL}

Mao Zedong, who led China's Communist Revolution and served as its supreme leader until his death in 1976, claimed to have read The Story of the 
Stone five times and urged others to do the same. He saw in it a tale of class struggle, putting it on the right side of communist ideology. Although briefly denounced as bourgeois, the novel was one of the few books people in China were permitted to read during the decade-long repressions of the Cultural Revolution.

It is tempting to read The Story of the Stone for its depiction of "traditional Chinese society" and assume-as Mao Zedong clearly did-that the novel accurately reflects it. The author incorporated in great detail the religious rites, social rituals, arts and music, games and festivities, medical theories, laws and regulations, and government institutions of the world in which he lived. Although he mentioned objects such as watches, clocks, eyeglasses, full-length mirrors, and tobacco that were unavailable in China before his time, he insisted, in the very first chapter, that the dynasty in which the story takes place is indeterminate. The name of the "capital city" is never revealed; titles of government officials are drawn from different periods of history. Not counting Jia Baoyu's outlandish braid, there is only one reference to a man wearing a queue, a practice that the conquering Manchus imposed on the entire population when they took over the country in the mid-seventeenth century. The vague setting of the novel helps to project an aura of timelessness and universality.

One must, of course, exercise caution with the designation of "traditionally Chinese." Who is to say that something is representative of a tradition? There are, however, some widely acknowledged cultural threads running persistently across Chinese communities, urban and rural, dating back at least several hundred years. Take the annual festivals featured in the novel: Lunar New Year, the Lantern Festival, Spring Cleaning (also known as Tomb Sweeping Day), the Double Five (also known as the Dragon Boat Festival), the Double Seven, the Double Nine, the Mid-autumn (Mooncake Day), and Nibbansday (Laba, the eighth day of the twelfth month). Except for the Grain in Ear Day mentioned in chapter 27, they are all still celebrated in many Chinese communities today. It can be argued that reading The Story of the Stone for its depiction of traditional cultural practices is no more egregious than plumbing Jane Austen's Pride and Prejudice, William Makepeace Thackeray's Vanity Fair, or George Eliot's Middlemarch for British mores, as these novels also show people grappling with the established norms of a stable, complex society.

However, far from being a historical or social document, a religious or political tract, or a dry philosophical treatise, The Story of the Stone is a tale 
that Cao Xueqin wrote to comfort himself and to entertain his friends and relatives. His fan base has been expanding ever since.

Nevertheless, the novel poses a special challenge for present-day readers. Written in an era when the literate elite had limited entertainment options and typically plenty of leisure time, The Story of the Stone is meant to be chewed over and reread. Not only is it very long and the relationships among its characters highly complicated, but also it operates simultaneously on realistic and mythic levels. Moreover, a number of subplots weave in and out of its 120 chapters, and the significance of some episodes does not become apparent until scores of chapters later. With each rereading, the story is supposed to come into sharper focus. To have read the novel five times was not unusual for an educated Chinese of Mao Zedong's generation. But how many readers of today can be expected to puzzle out the subtle intricacies of this long novel by reading it over and over again? Faced continually with perplexing passagesthe first five chapters are especially challenging-they are liable to simply give up on a work that could have given them immense pleasure.

Every reader brings to any piece of literature his or her own perspective. It has been observed that one's interpretation of The Story of the Stone changes as one goes through different stages in life. This guide reflects the cumulative reading and life experiences of its authors. Over time, the persistent reader will develop his or her own take on this marvelous masterpiece. Our aim is to provide English readers with sufficient cultural and narrative context so that they can savor the story, even reading it-in full or in part-for the very first time. Enjoy! 
